\title{
The Type of Paired Synonym of Intransitive Verbs $k e$-an in Indonesian
}

\author{
Afrinaldi, Ngusman Abdul Manaf, Novia Juita \\ Universitas Negeri Padang \\ afrinaldi419@yahoo.com
}

\begin{abstract}
A number of articles about synonyms have been written, but have not given a thorough explanation. The article on synonyms by previous researchers only addresses the same element of meaning in synonymous words, but lacks the kind of synonyms. The writing of this article is done to explain the type of synonym of the intransitive verbs ke-an in Indonesian. This type of research is qualitative by using the descriptive method. Sources of research data are written text of Indonesian language that is Kompas newspaper, oral speech at news event Liputan 6, and intuitive researcher. The results of this study indicate that (1) not all intransitive verbs ke-an in Indonesian have synonym pairs, (2)the pair intransitive verbs ke-an in Indonesian have an incomplete and not absolute synonym type.Therefore, Indonesian speakers need to pay attention to the use of words that have different meanings.
\end{abstract}

Keywords--Intransitive verbs ke-an; Synonym types; Indonesian language

\section{INTRODUCTION}

Research on synonyms has been done by a number of people, but the research generally discusses the meaning equations and has not yet fully explained the types in synonyms. People who have done research on synonyms are Edmonds, P., and Hirst, G. (2002) researching synonyms and selection of words whose results are synonyms can affect the lexicon structure of word selection. Taylor, J.R. (2002) examines the close synonyms in the hight and tall adjective categories that the result is that the hight and tall adjective has a meaning equation but is different when it is entered by the sentence. Webb, S. (2007) examines the effect of synonyms in the teaching of a second language vocabulary whose results are synonymous with interconnected relationships simultaneously meaning to make a sharper and more precise distinction. Ekoyanantiasih, R., \& Winarti, S. (2010) examines the relation of the meaning of synonym in human noun which result is synonym has a meaning relation in human insanity noun. Utami, R. (2010) examines the synonyms of nouns in the Indonesian language that the result is that no nouns are absolute synonyms and most are only close synonymous. Ana, Sisilia A. (2013) examined the synonyms of human nouns in the Sekadau dialect of the Malay language which the result is to show that the synonym of a human noun in Melayu Sekalu melalek has a meaning field and a component of meaning. Rahmatika, Erika. (2013) examines the synonyms of nouns and adjectives in Banyumasan dialect which results in the classification of the form and the causal factors of the noun synonyms and adjectives in the Banyumasan dialect. Hassan, A.E. (2014) examined the recitation of synonymous translations in the Qur'an whose result was to find a synonymous word but in its use could not replace each other. Suryatin, E. (2014) examined the semantic verb meaning 'hurt' in the Banjar language that the result is a verb 'hurt' is divided into three that is hurting by hand, foot, and tool. Zulfadinamis, Nurulhayati. (2015) examined the concept of synonym in the novel translation of The Pearl into Malay which the result is to show that there are several synonymous concepts known in the text. Dangli, L., and Abazaj, G. (2014) examine the lexical cohesion of choice of words and synonyms in academic writing whose outcome is that the correct use of synonyms in the writing process can add color and precision to the text. Idiatussaufiah (2015) examines the synonyms of the word khamr in Arabic in the dictionary of Al-Munawwir Arab Indonesia which results are found some words that are considered synonymous with the word khamr in Al-Munawwir arab-Indonesia dictionary. Herlina, H. (2016) examined variations of nuance meaning of verbs of Sanggau Malay, West Kalimantan, whose result is a word similar to the meaning intended by the speaker should be adjusted to the situation and condition when the event said.

Relevant research based on the search of this study, it can be seen that the type of synonym of the pair of intransitive verbs ke-an in Indonesian until the latest year (2017) has not been fully explained. Accordingly, this article is written to describe the kind of synonym of intransitive verbs ke-an in the Indonesian language. The type of synonym of intransitive verbs ke-an in the Indonesian language, which as far as researchers do on search results has not been completely explained. In order to avoid errors in communicating, this study is important because it provides knowledge for language users. In addition, this article is more detailed than previous research, which uses two stages of testing (component test, and substitution test). The purpose of this study was to explain the type of synonym of intransitive verbs $k e$-an in the Indonesian language. 
Synonyms are two or more words that have the same meaning (Cruse, D. A., 2000). Sugono, D. (2008) explains that synonyms are a form of language whose meaning is similar to or similar to other forms of language. Lyons (1981) distinguishes a perfectly synonymous word with an absolute synonymous word. A word is said to be perfectly synonymized when the words contain the same descriptive, expressive, and social meanings, while a word is singly synonymized when the words have the same and perfectly meaningful distribution in its presence in all contexts.

According to Lyons, J. (1977), synonyms are divided into four groups, namely complete and absolute synonyms, complete synonyms but not absolute, synonyms incomplete but absolute, and synonyms incomplete and not absolute. Lyons argues that synonyms are complete when cognitive meanings are the same as emotive meanings, whereas synonyms are absolute for synonyms that can replace each other in all contexts. Lyons, J and Ulman, S. (1972) state that complete and absolute synonyms are hard to find. Palmer, F.R. (1976) states that it happens because in a language there is no reason to keep two words of the same meaning.

The intransitive verbs derived by the fictional konfiks ke-an can be divided into three groups, which are (1) nominated one, (2) mandatory two and mandatory, and (3) nominate two, but the second nominee is money overheating. The basis used may be verbs, adjectives, or nouns (Alwi, H. 2003, p.145). Example:

1. kelaparan : Kami kelaparan.

kedinginan : Mereka kedinginan.

kepanasan : Anak itu kepanasan.

3. kebanjiran : Kita kebanjiran (barang Jepang)

kehujanan : Kami kehujanan (salju)

1. starvation: We are hungry. coldness: They're cold. child is overheated.

3. flooded: We are flooded (Japanese goods)

rain: We rain (snow)

2. kejatuhan : Petani itu kejatuhan kelapa

kehabisan : Sekarang kami sudah kehabisan uang

kehilangan : Kemarin saya kehilangan dompet

2. fall: The farmer is the fall of the coconut

running out: Now we're running out of money overheating: The

lost: Yesterday I lost my wallet.

\section{METHODS}

Type of this research was qualitative research by using descriptive method. This research was aimed to obtain the description and explanation of the types of intransitive synonym verbs ke-an in Indonesian language. Research data was oral and written form derived from written reading material (Kompas newspaper, Indonesian textbook), informant's speech at Liputan 6 news event, and researcher's intuition. Meanwhile, the researcher as a research instrument accompanied with the data collection and analysis table. The data collection technique was document recording, tapping techniques, and introspection techniques. The data were analyzed by determining the cognitive meaning of each intransitive verbs ke-an. The purpose of determining meaning was to determine intransitive verbs ke-an pairs that are synonymous based on the basis of their common meaning. Furthermore, data reduction was done because not all inferential confounding intransitive verbs $k e$-an have a synonymous pair. To prove that the pair was truly synonymous, two stages of testing were tested for component meaning and substitution test.

\section{FINDING AND DISCUSSION}

\section{Pair Synonyms of Intransitive Verbs Konfiks ke-an in the Indonesian Language}

Based on research data about intransitive verbs ke-an in the Indonesian language, found as many as 15 couples are estimated to be synonymous. The pair of words that are estimated to be synonymous is tested for their synonyms based on the analysis of the meaning components such as the example of the synonymous analysis of the following words of fear (ketakutan) and anxiety (kecemasan). 
Table 1

Component Analysis of Meaning of Verbs Intransitive fear (ketakutan) and anxiety (kecemasan)

\begin{tabular}{lllcc}
\hline \multirow{2}{*}{ No } & \multicolumn{2}{c}{ Component of Meaning } & \multicolumn{2}{c}{ Intimate pair of intransitive verbs } \\
\cline { 3 - 5 } & & fear & anxiety \\
\hline \multirow{2}{*}{1.} & Cognitive & WORRIED & + & + \\
\cline { 3 - 5 } & & WORRIES & + & + \\
\cline { 2 - 4 } & & NERVES & + & + \\
\cline { 2 - 4 } & EVERSION & FINE & + & + \\
\hline 2. & Emotive & FIN & + & + \\
\hline
\end{tabular}

After testing the component of meaning in table 1, the intransitive verb pair of fear and anxiety have the meaning of WORRIED,WORRIES, ANXIETY, and FINE. The comparison between the word fear and anxiety has 4 equations of meaning $(80 \%)$ of the 5 elements of meaning being compared. Therefore, intransitive verbs of fear and anxiety are synonymous because the word pair has the same meaning element over $50 \%$.

In addition to being tested component analysis, the synonym of intransitive verbs ke-an in the Indonesian language is also tested by substitution techniques such as the example of intransitive verb variance analysis of intense fear and anxiety. The intransitive verb substitution test of fear and anxiety can be seen in the context of sentences ... began to appear after the events of yesterday such as examples (1) and (2).

(1) Their fears began to appear after the events of yesterday.

(2) Their anxiety began to appear after the events of yesterday.

Intransitive verb of fear and anxiety can replace each other in the context of sentences (1) and (2) with relative or unchanged meanings. Based on the substitution test on the intransitive verb pair of fear and anxiety, the intransitive verb pair is declared synonymous. The meaning of intransitive verbs of fear and anxiety is a state of worry and anxiety about a thing.

Based on the results of the test of synonymity with the component analysis test of meaning as in table 1 and substitution tests such as substitution in sentences (1) and (2), obtained 9 pairs synonym of intransitive verbs ke-an in indonesian language which proved to be synonymous and can be seen in table 2 .

Table 2

Intransitive Verb ke-an Pairs Based on Analysis Results Components of Meaning and Substitution

\begin{tabular}{|c|c|c|c|}
\hline \multirow{3}{*}{ No. } & \multicolumn{2}{|c|}{ Couple Synonym Verba Intransitif konfiks ke- } & \multirow{3}{*}{ Equations Meaning } \\
\hline & & & \\
\hline & $\mathrm{A}$ & $\mathrm{B}$ & \\
\hline 1. & $\begin{array}{l}\text { kedinginan } \\
\text { (coldness) }\end{array}$ & kesejukan (coolness) & coldness coolness under normal temperature \\
\hline 2. & kepanasan (heat) & kehangatan (warmth) & $\begin{array}{l}\text { the warmth of the temperature of the temperature } \\
\text { above the normal average }\end{array}$ \\
\hline 3. & kejatuhan (fall) & keruntuhan (collapse) & falling collapse hit something falling down \\
\hline 4. & $\begin{array}{l}\text { kemasukan } \\
\text { (conceded) }\end{array}$ & $\begin{array}{l}\text { kerasukan } \\
\text { (possessed) }\end{array}$ & $\begin{array}{l}\text { possession entered into something into the human } \\
\text { body }\end{array}$ \\
\hline 5. & kecurian (stealing) & kemalingan (theft) & $\begin{array}{l}\text { Stealing theft of loss of something because people } \\
\text { are taken }\end{array}$ \\
\hline 6. & $\begin{array}{l}\text { ketahuan } \\
\text { (discovered) }\end{array}$ & kedapatan (caught) & found out was known about something \\
\hline 7. & ketakutan (fear) & kecemasan (anxiety) & fear anxiety about the state of anxiety or anxiety \\
\hline 8. & kelelahan (fatigue) & keletihan (fatigue) & fatigue state about the body that is not powerful \\
\hline 9 & kemajuan (progress) & kesuksesan (success) & $\begin{array}{l}\text { progress on the success of the advanced state of } \\
\text { intelligence and success }\end{array}$ \\
\hline
\end{tabular}




\section{Kind of Synonymity of Intransitive Verbs ke-an in the Indonesian Language}

After obtaining 9 pairs of synonym of intransitive verbs ke-an in the Indonesian language, each pair of intransitive verbs ke-an is analyzed by the type of synonym. The type of synonym is determined by the degree of similarity of the elements of cognitive meaning and the emotive meaning element, and the ability of a synonym pair to be mutually substituted in the context of the same sentence. Based on the component component test of meaning and substitution capability in the same context of 9 pairs of synonyms of intransitive verbs ke-an in Indonesian language, it is found that the types of synonyms are incomplete and not absolute.

\section{Synonyms are Incomplete and not Absolute}

Analyze the type of synonym is incomplete and not exemplified in the intransitive verb pair of overheating (kepanasan) and warmth (kehangatan) following.

Table 3

Component Meaning Analysis Verba Intransitive heat (kepanasan) and warmth (kehangatan)

\begin{tabular}{lllcc}
\hline \multirow{2}{*}{ No } & \multicolumn{2}{c}{ Component of Meaning } & \multicolumn{2}{c}{ Intimate pair of intransitive } \\
& & \multicolumn{2}{c}{ verbs } \\
\cline { 3 - 4 } & & heat & warmth \\
\hline \multirow{2}{*}{ 1. Cognitive } & WEAVEN SUN HEAT & + & + \\
\cline { 3 - 4 } & & RELATIVE TOUCH HIGH & + & + \\
\cline { 3 - 4 } & EOO HOT & + & + \\
\cline { 3 - 4 } & GOOD DELIVERY (GLAD AND JOY) & - & + \\
\hline 2. & FINE & & + \\
\hline
\end{tabular}

Based on the component meaning analysis in table 3 , the cognitive meaning of intransitive verbs heat and warmth has different meanings. The intransitive verbs of heat and warmth have an incomplete type of synonym because there is a difference of cognitive meaning too hot and a state of joy, intransitive verbs heat have the meaning of relatively high temperatures, whereas intransitive verbs warmth have a slightly higher mean state. Therefore, intransitive verbs heat and warmth have an incomplete synonym type.

Furthermore, intransitive verb heat and warmth is analyzed by the type of synonym with substitution test. The intransitive verb substitution test of heat and warmth can be seen in the context of sentence a mother's affection gives her ... in her household as in examples (3) and (4).

(3) A mother's affection gives her warmth in her household.

(4) *A mother's affection gives her heat in her household.

Irritant intransitive verbs heat are unacceptable to occupy in the context of a mother's affection gives her ... in her household as in example (3). In contrast, intransitive verbs warmth is acceptable to occupy in the context of a mother's affection gives her ... in her household as in example (4). Intransitive verbs of heat and warmth can not be replaced with each other in the context of a particular sentence, and the intransitive verb is classified as an absolute type of synonym. Based on these analyzes (the similarity of the elements of meaning and the ability to replace each other in the context of the same sentence), intransitive verb heat and warmth belong to the type of synonym is incomplete and not absolute.

After analyzing the 9 pair of intransitive verbs konfiks ke-an in Indonesian language, there were 9 pairs of intransitive verbs ke-an in Indonesian language which were classified as incomplete and non-absolute synonyms, ie (1) coldness and coolness, (2) heat and warmth, (3) fall and collapse, (4) conceded and possessed, (5) stealing and theft, (6) discovered and caught, (7) fear and anxiety (8) fatigue and fatigue, and (9) progress and success.

The results of this study indicate that the pair of synonymous intransitive verbs ke-an in the Indonesian language has the type of synonyms incomplete and not absolute. So there is no synonym pair having equations of the same meaning element perfectly and synonym pairs can only be replaced with each other in the context of a particular sentence. Therefore, Indonesian speakers need to pay attention to the use of words that have different meanings.

The results of this study are in line with the results of research conducted Utami (2010) synonym of nouns in the Indonesian language, Ana (2013) synonym of human noun in Sekadau dialect, and Zulfadinamis (2015) the concept of synonym in the novel translation text "The Pearl" into Malay. Compared with the results of previous research, the novelty of the results of this study, Utami (2010), Ana (2013), and Zulfadinamis (2015) are these results indicate that the intransitive verbs ke-an in the Indonesian language have the kind of synonyms incomplete and not absolute. While the results of previous relevant research do not explain the type of synonym pair. 


\section{CONCLUSION}

Based on the analysis that has been done on about the type of synonym of intransitive verbs $k e$-an in the Indonesian language, obtained the following two conclusions. Firstly, not all intransitive verbs ke-an in the Indonesian language have synonym pairs. Secondly, the pair of intransitive verbs konfiks $k e$-an in the Indonesian language has an incomplete and non-absolute synonym type. This indicates that the pair of synonym of intransitive verbs ke-an in the Indonesian language can only replace each other in the context of a particular sentence.

The language or community users should be more careful in performing Indonesian language. For advanced researchers, to be able to conduct further research regarding the synonymous nature of expanding and developing studies in synonymy.

\section{References}

Ana, Sisilia A. (2013). Kesinoniman noun Insani in Malay dialect Sekadau. Skripsi. UTP Pontianak.

Alwi, H. (2003). Indonesian standard grammar. Jakarta: Balai Pustaka.

Cruse, D. A. (2000). Meaning in language: an introduction to semantics and pragmatics. Cambridge: Cambridge University Press.

Dangli, L., and Abazaj, G. (2014). Lexical cohesion, word choice and synonymy in academic writing. Mediterranean Journal of Social Sciences, 5 (14), 628-632

Edmonds, P., and Hirst, G. (2002) Near synonymy and lexical choice. Computational Linguistics, 28 (2), 105-144.

Ekoyanantiasih, R. \& Winarti, S. (2010) The relation of the meaning of synonymity in human nouns in Indonesia. Jakarta: Kemendiknas.

Hassan, A.E. (2014). Readdressing the translation of near synonymy in the glorious qur'an. European Scientific Journal, $10(8), 165-191$.

Herlina, H. (2016). Variations and nuances of verbal meaning of West Kalimantan sanggau verb. Prosiding PRASASTI, 386-390.

Idiatussaufiah. (2015). Synonym khamr word in Arabic on Al-Munawwir Arab-Indonesia dictionary (1997). Tesis. UIN Yogyakarta.

Lyons, J. (1977). Semantics I. Cambridge: Cambridge University Press.

Palmer, F.R. (1976). Semantics a new outline. Cambridge: Cambridge University Press

Rahmatika, Erika. (2013). Noun synonyms and Banyumasan dialect adjectives. Skripsi. UNS Semarang.

Sugono, D. (2008). Great Indonesian Dictionary of the fourth edition language center. Jakarta: Gramedia Pustaka Utama.

Suryatin, E. (2014). Semantic analysis of verbs means 'harm' in the Banjar language. Metalingua, 2(1), 43-56.

Taylor, J. R. (2002). Near synonyms as co-extensive categories: 'high' and 'tall' revisited. Language Sciences, 25, 263-284.

Ulman, S. (1972). Semantics and introduction to the Science of Meaning. Oxford: Basil Blackwell.

Utami, R. (2010). Study of the noun synonym in Indonesian. Tesis. UNS Surakarta.

Webb, S. (2007). The effects of synonymy on second language vocabulary learning. Reading in a Foreign Language, 19 (2), 121-122.

Zulfadinamis, Nurulhayati. (2015). The concept of synonym in the translation text of the novel "the pearl" to In Malay by Abdullah Hussain. Journal of Business and Social Development, 3 (2) 80-95. 